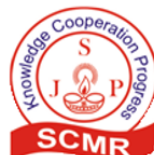

International Journal of Engineering Sciences 2019 12(1) 8-14

INTERNATIONAL JOURNAL

$\mathrm{OF}$

ENGINEERING SCIENCES

\title{
Nano indentation Analysis of Multi Stage Spark Plasma Sintered Hydroxyapatite-Calcium Titanate Biocomposite
}

\author{
Prafulla Kumar Mallik*, Kantesh Balani", Bikramjit Basu ${ }^{\$}$ \\ *Department of Metallurgical and Materials Engineering, IGIT Sarang, Odisha, India

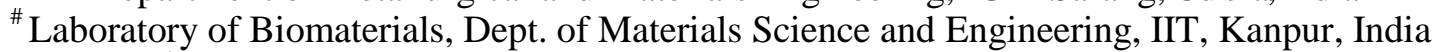 \\ ${ }^{\$}$ Materials Research Centre, Indian Institute of Science, Bangalore, India \\ (Received 9 September 2018; accepted 27 February 2019) \\ https://doi.org/10.36224/ijes. 120102
}

\begin{abstract}
Despite being highly bioactive and biocompatible, some of the limitations like poor fracture toughness, lack of electrical conductivity and antimicrobial properties restrict the use of monolith hydroxyapatite (HA) as bone replacement material. In this paper, we address one such issue and will demonstrate how $\mathrm{CaTiO}_{3}(\mathrm{CT})$ addition enhances physical properties like strength, fracture toughness etc. Therefore, the strategy in the current research is to develop dense HA-CT biocomposites using innovative multi-stage spark plasma sintering (MSSPS) technique (at $50 \mathrm{MPa}, 1200^{\circ} \mathrm{C}, 5 \mathrm{~min}$ ), that can mimic the function and properties close to that of natural bone. Fine scale microstructural characterization using TEM reveals the presence of twins in $\mathrm{CaTiO}_{3}$ grains and the grain size of $\mathrm{HA}$ is around $1-2 \mu \mathrm{m}$. Phase analysis using $\mathrm{x}$-ray diffraction analysis revealed an absence of $\alpha$ and $\beta$-tricalcium phosphate $\left(\mathrm{Ca}_{3}\left(\mathrm{PO}_{4}\right)_{2}\right)$ or $\mathrm{CaO}$ phase which is also supported by Fourier transformed infra-red spectroscopy. Elastic modulus of 46-135 GPA is obtained using nanoindentation. Based on the available empirical models, it has been observed that the experimentally measured density hardness, and elastic modulus match reasonably well with that of the natural cortical bone.
\end{abstract}

Keywords: Hydroxyapatite, Calcium titanate, Spark plasma sintering, Nanoindentation

\section{Introduction}

Hydroxyapatite has been used as synthetic biomaterials for orthopaedic research in last two decades due to its being highly bioactive and better osseointegration [1 - 2]. Because of the conventional processing of HA ceramics results insufficient fracture toughness $(\sim 1 \mathrm{MPa}$ $\mathrm{m}^{1 / 2}$ ) [3] for the load bearing hard tissue replacement. Therefore, HA-based composites have been developed by using different additives $\left(\mathrm{ZrO}_{2}, \mathrm{Al}_{2} \mathrm{O}_{3}\right.$, and $\mathrm{BaTiO}_{3}$ etc $)$ to improve the mechanical reliability [4-6]. It is reported that $\mathrm{CaTiO}_{3}(\mathrm{CT})$ is a good substrate for apatite growth [7] and plays a dominant role in osseointegration [8]. Also, CT has modest mechanical properties, including elastic modulus of $161 \mathrm{GPa}$, hardness of $5 \mathrm{GPa}$ [9] and fracture strength of $172 \mathrm{MPa}$ [10]. It is to be noted that $95 \%$ densification of $\mathrm{HA}-\mathrm{CaTiO}_{3}$ (HA-CT) composites was achieved by pressureless sintering at $1400^{\circ} \mathrm{C}$ for 4 hours [11]. The present work reports the development of $\mathrm{HA}-\mathrm{CaTiO}_{3}$ based biocomposites with varying content of $0,40,80$, and $100 \mathrm{wt} \% \mathrm{CaTiO}_{3}$ by using multi stage spark plasma sintering (MSSPS) [12]. Such advanced technique enables faster heating rate $\left(100-200{ }^{\circ} \mathrm{C} / \mathrm{min}\right)$, shorter holding time (5 min) and simultaneously higher applied pressure (30-100 $\mathrm{MPa}$ ), which can produce dense HA-based biomaterials, when compared to this from conventional sintering [13]. The major thrust in this paper is to present the results of detailed microstructure and mechanical characterisation using nanoindentation technique. Further,

${ }^{*}$ Corresponding author

Email address: prafulla.mallik@gmail.com (Prafulla Kumar Mallik)

ISSN 0976 - 6693. (O2019 SCMR All rights reserved. 
analytical models are utilized to correlate the densification to that of obtained mechanical properties.

\section{Materials and methods}

\subsection{Sample preparation}

Hydroxyapatite $\mathrm{Ca}_{10}\left(\mathrm{PO}_{4}\right)_{6}(\mathrm{OH})_{2}$ powder was synthesized using precursors $\mathrm{CaO}$ and orthophosphoring acid adopting wet precipitation route [14]. Also, the crystalline calcium titanate $\left(\mathrm{CaTiO}_{3}\right)$ was synthesized by ball milling from the mixture of $\mathrm{CaO}$ and $\mathrm{TiO}_{2}$ (anatase) followed by calcination at $900^{\circ} \mathrm{C}$ for $2 \mathrm{hrs} \mathrm{[15].} \mathrm{HA-CT} \mathrm{powders} \mathrm{were} \mathrm{made} \mathrm{by} \mathrm{ball}$ milling (Fritsch, Pulverisette 1583, Germany) for $16 \mathrm{hr}$ using agate balls and jars as grinding media with varying amounts of $\mathrm{CaTiO}_{3}(40,80 \mathrm{wt}$. \%) to HA. The innovative multistage spark plasma sintering technique (MSSPS) (Dr. Sinter, Model 515S, SPS syntax Inc, Japan) was used to sinter the powders using two heating cycles as shown in Table.1. The novelty of the process was that the powders (HA-40CT, HA-80CT and CT) were loaded into the graphite die by simultaneously applying uniaxial pressure of $50 \mathrm{MPa}$ and were heated by pulsed direct current to a temperature of $850^{\circ} \mathrm{C}$ (holding time of 5 minutes) to enhance the surface activation. In the same heating cycle, the powder compact was subsequently heated to a temperature of $950^{\circ} \mathrm{C}$ with a dwell time of 5 min to activate the surface diffusion, followed by final stage of sintering at temperature of $1200^{\circ} \mathrm{C}$ for holding time 5 min to promote the lattice diffusion and plastic deformation. On the other hand, HA powder was heated at pressure of $30 \mathrm{MPa}$ with sintering temperature of $850{ }^{\circ} \mathrm{C}, 950{ }^{\circ} \mathrm{C}$ with holding for 5 min at each temperature and finally sintered at $1000{ }^{\circ} \mathrm{C}$. A uniform heating rate of $100^{\circ} \mathrm{C} / \mathrm{min}$ was maintained throughout of the sintering cycle for all the samples followed by furnace cooling. Finally, all the SPSed samples were polished using a series of emery papers to produce flat mirror surfaces for further studies.

\subsection{Characterisation of composites}

The bulk density of the HACT composites was measured using Archimedes' principle. In order to calculate the percentage of relative theoretical density ( $\%$ TD), the measured density was compared to the theoretical density of $\mathrm{HA}(3.16 \mathrm{~g} / \mathrm{cc})$ and $\mathrm{CaTiO}_{3}(3.9$ $\mathrm{g} / \mathrm{cc})$. The stability and dissociation of HA phases in the sintered HA-CT composites were analysed by XRD (Bruker Xpert diffractometer) using $\mathrm{Cu}-\mathrm{K}_{\alpha}(1.54 \AA$ ) radiation. The microstructure of polished and chemically etched samples was obtained using Scanning Electron Microscope (SEM, FEI Quanta 200). Additionally, electron transparent ultrathin samples of $0.1 \mu \mathrm{m}$ or lower thickness were prepared using ultrasonic disc cutter followed by dimpling and precision ion polishing system (PIPS). Transmission Electron Microscope (TEM, Tecnai $\mathrm{G}^{2}$ ) was used to study the microstructure and morphology of the phases in monolith HA, CT and HA-CT composites. Elastic modulus and hardness were determined by nanoindentation technique (Hysitron Minneapolis, USA) using Berkovich indenter at load of $6 \mu \mathrm{N}$ and $4 \times 4$ numbers of indentation. 


\section{Results and discussion}

\subsection{Densification and Microstructural analysis}

All the multi-stage sintered ceramics achieved density of $98 \%$ of theoretical density or more, of which $\sim 99 \%$ of theoretical density is obtained for HA and HA40CT ceramics (heating rate of $100{ }^{\circ} \mathrm{C}$, pressure of $30-50 \mathrm{MPa}$, holding time $5 \mathrm{~min}$ ).. In conventional sintering, 95\% relative density was achieved when sintered at $1400{ }^{\circ} \mathrm{C}$ for similar HA-CT composition for 4 hour.11 The efficacy of multi stage spark plasma technique in densifying HA-CT composites can be realised due to fast heating rate, short holding time in combination with applied pressure. The majority of the XRD peaks corresponds to the characteristic peaks of HA and CT as shown in the Fig. 1. The stability of phases in HACT composites was therefore confirmed. An absence of $\alpha$ and $\beta$-tricalcium phosphate $\left(\mathrm{Ca}_{3}\left(\mathrm{PO}_{4}\right)_{2}\right)$ and $\mathrm{CaO}$ peaks were critically recorded, which is detrimental to mechanical properties. However, the major X-ray peaks of $\mathrm{CaTiO}_{3}$ phase were shifted to lower $2 \theta$ of $\sim 0.4^{\circ}$, which were noticed in the sintered HA80CT composite and monolith CT. Also, very weak peak of $\mathrm{TiO}_{2}$ was observed in XRD spectrum of $\mathrm{CaTiO}_{3}$. Fig.2 (a) shows the SEM and (b) TEM fine grained $(0.5-2.0 \mu \mathrm{m})$ homogeneous microstructures of CT HA-40CT and HA80CT composites. It is assumed that the equiaxed grains are formed during MSSPS sintering, which corresponds to the phase $\mathrm{CaTiO}_{3}$ and HA as seen in Fig. 2(a). As a result, diffusion mechanisms of $\mathrm{CaTiO}_{3}$ and $\mathrm{HA}$ grains take place during final stage of sintering and only small amount of porosity can observed at the triple point of grain boundary in the HA-CT ceramics.

\subsection{Hardness and Elastic Modulus}

The typical nanoindentation Load -displacement curve of monolith of HA, CT ,HA40CT and HA80CT composites is represented by the indenter load, $\mathrm{P}$, as a function of the apparent depth of penetration, $h$ as shown in Fig. 3(a). Based on the curve $\mathrm{P}(\mathrm{h})$, important properties includes hardness and elastic modulus can be derived according to following equations.

$\mathrm{P}=\mathrm{P}(\mathrm{h}), \mathrm{S}_{\mathrm{m}}=\frac{\mathrm{dP}}{\mathrm{dh}} \mid \mathrm{h}=\mathrm{h}_{\mathrm{m}}=\frac{2}{\sqrt{\pi}} \mathrm{E}_{\mathrm{r}} \sqrt{\mathrm{A}\left(\mathrm{h}_{\mathrm{p}}\right)}$

Nanoindentation hardness is generally defined as the indentation load divided by the projected contact area of the indentation. It is the mean pressure that a material can resist to deform under load. The hardness can be obtained from the load - displacement curve of monolith of HA, CT and HA-CT composites at peak load $\mathrm{P}_{\max }$ as shown in Table 2.

$\mathrm{H}=\frac{\mathrm{P}_{\max }}{\mathrm{A}\left(\mathrm{h}_{\mathrm{c}}\right)}$

where, $\mathrm{A}\left(\mathrm{h}_{\mathrm{c}}\right)$ is the projected contact area, which is calculated as a function of contact depth, $\mathrm{h}_{\mathrm{c}}$, with the sample under load. It can be determined from the load- displacement curve using equation

$\mathrm{h}_{\mathrm{c}}=\mathrm{h}_{\max }-\varepsilon \frac{\mathrm{P}_{\max }}{\mathrm{S}}$

where, $h_{\max }$ is the displacement at the peak load $\left(\mathrm{P}_{\max }\right) . \mathrm{S}$ is the slop of initial

unloading curve and contact stiffness at maximum depth of indentation. $\varepsilon$, is a constant that 
depends on the indenter geometry ( $\varepsilon=0.75$ for a Berkovich indenter).

However, contact stiffness, $\mathrm{S}$ can be derived from using Sneddon the geometrical relation between contact area, $\mathrm{A}\left(\mathrm{h}_{\mathrm{c}}\right)$ and where, $\beta$ is a constant that depends on the geometry of the indenter $\left(\beta=1.034\right.$ for a Berkovich indenter). $E_{r}$ is reduced elastic modulus, which indicates the elastic deformation occurs in both the sample and the indenter during indentation and given by equation 4 .

$$
\frac{1}{E_{\mathrm{r}}}=\frac{\left(1-\mathrm{v}^{2}\right)}{\mathrm{E}}+\frac{\left(1-\mathrm{v}_{\mathrm{i}}^{2}\right)}{\mathrm{E}_{\mathrm{i}}}
$$

where, E and $v$ are the elastic modulus and Poisson's ratio for the monolith HA, CT and HA- CT composites, respectively, and $E_{i}$ and $v_{i}$ are the elastic modulus and Poisson's ratio for the indenter. For diamond, $E_{i}=1141 \mathrm{GPa}$ and $v_{i}=0.07 .^{24}$ To determine elastic modulus, E of monolith HA, CT and HA-CT composites using equation (3) and (4) from the contact stiffness and the projected contact area values can be calculated from the load-displacement curve as shown in the Table 2.

Elastic modulus and hardness values obtained from nanoindentation data is plotted as the function of $\mathrm{CaTiO}_{3}$ content as shown in Fig. 3(b). The elastic modulus values of HACT ceramics increase with increasing the quantity of $\mathrm{CaTiO}_{3}$, sintering temperature and pressure. The maximum values of elastic modulus obtained in monolith CT was $250 \mathrm{MPa}$ at pressure $50 \mathrm{MPa}$ and sintering temperature of $1200{ }^{\circ} \mathrm{C}$, whereas minimum value observed in monolith HA ceramics was $99 \mathrm{MPa}$ at pressure $30 \mathrm{MPa}$ and sintering temperature $1000{ }^{\circ} \mathrm{C}$. Similarly hardness values of HACT ceramics increase with increasing the amount of $\mathrm{CaTiO}_{3}$ content in monolith HA. The maximum values of hardness obtained in monolith $\mathrm{CaTiO} 3$ was $5 \mathrm{GPa}$ whereas the hardness obtained in monolith HA was $3.2 \mathrm{GPa}$.

From the analysis of the load- displacement curve (Fig. 2(a)), it can be observed that the shape of load displacement curve has shifted towards right as increasing the loading of $\mathrm{CaTiO}_{3}$ ceramics to monolith HA. This indicates the increasing the quantity of CT into the matrix of HA results decreasing in the slop and depth of indentation of the curve of HACT ceramics, which implies increasing in stiffness and hardness as decreasing the depth of indentation as shown in Fig.2 (b). The present study has combined consideration of the elastic

modulus, flexural strength and fracture toughness data to express the overall effects of processing and microstructure. An optimal sintering profile is chosen in order to control the grain size and porosity. The highest density of $98 \%$ of theoretical density was obtained in most of the HA-CT composites with fine grained microstructural features. However, it was reported that above $95 \%$ of theoretical density, the grain size is the dominant factor for mechanical properties.

Moreover, the elastic modulus of HA-CT composites was related to the bulk density through the empirical models as shown in Fig. 3(a), which indicates that the density of composites is increased with increasing elastic modulus and fall in between these models. As a result, the developed composites deviate from the predicted values for cortical bone, which is due to higher elastic modulus and densities of both HA and CT. However, natural bone consists of nano scale hierarchical structure of apatite crystallites and its heterogeneous distribution of collagen fibres, which attributes higher elastic modulus at lower apparent density.

\section{Conclusion}

It can be concluded that the addition of $\mathrm{CaTiO}_{3}$ to $\mathrm{HA}$ matrix plays an important role in determining strength and toughness of HA-CT composites. It is hard enough to achieve 
desired mechanical properties compared to natural cortical bone under controlled HA-CT interaction, and microstructure using optimised MSSPS sintering profile. Importantly, good thermomechanical compatibility between $\mathrm{HA}$ and $\mathrm{CaTiO}_{3}$ is also demonstrated in the present work.

Table 1: The sinter densities, phase assemblage of multi-stage SPSed HA-CT composites. A detailed description of heating cycle is shown in Fig.1

\begin{tabular}{lllll} 
Sintering profile & $\begin{array}{l}\text { Sample } \\
\text { designation }\end{array}$ & $\begin{array}{l}\text { Amount } \\
\text { of CT } \\
(\text { wt } \%)\end{array}$ & XRD & $\begin{array}{l}\text { Sintered } \\
\text { density } \\
\left(\% \rho_{\text {th }}\right)\end{array}$ \\
\hline $850^{\circ} \mathrm{C} / 950^{\circ} \mathrm{C} / 1000^{\circ} \mathrm{C}$ & HA & 0 & Phase stability & 99.4 \\
$950^{\circ} \mathrm{C} / 1100^{\circ} \mathrm{C} / 1200^{\circ} \mathrm{C}$ & $\mathrm{CT}$ & 100 & $\begin{array}{l}\text { Phase of } \mathrm{TiO}_{2} / / 2 \theta \\
\text { shifting }\end{array}$ & 98.2 \\
$950^{\circ} \mathrm{C} / 1100^{\circ} \mathrm{C} / 1200^{\circ} \mathrm{C}$ & HA40CT & 40 & $\begin{array}{l}\text { Phase stability } \\
\text { Phase stability } / 2 \theta\end{array}$ & 99.0 \\
$950^{\circ} \mathrm{C} / 1100^{\circ} \mathrm{C} / 1200^{\circ} \mathrm{C}$ & HA80CT & 80 & $\begin{array}{l}\text { Phifting } \\
\text { she }\end{array}$ & \\
\hline
\end{tabular}

Table 2: Summary of the results of nanoindentation of monolith HA, CT and HA-CT composites

\begin{tabular}{llllll} 
Samples & $\begin{array}{l}\text { Load } \\
(\mu \mathrm{N})\end{array}$ & $\begin{array}{l}\text { Depth of } \\
\text { Penetration } \\
(\mathrm{nm})\end{array}$ & $\begin{array}{l}\text { Hardness } \\
(\mathrm{GPa})\end{array}$ & $\begin{array}{l}\text { Reduced Elastic } \\
\text { modulus, } \mathrm{E}_{\mathrm{r}} \\
(\mathrm{GPa})\end{array}$ & $\begin{array}{l}\text { Elastic } \\
\text { Modulus } \\
(\mathrm{GPa})\end{array}$ \\
\hline HA & 6 & 186 & 3.2 & 48 & 46 \\
$\mathrm{CT}$ & 6 & 190 & 5 & 128 & 135 \\
HA40CT & 6 & 209 & 3.5 & 122 & 121 \\
HA80CT & 6 & 174 & 4.5 & 123 & 127 \\
\hline
\end{tabular}
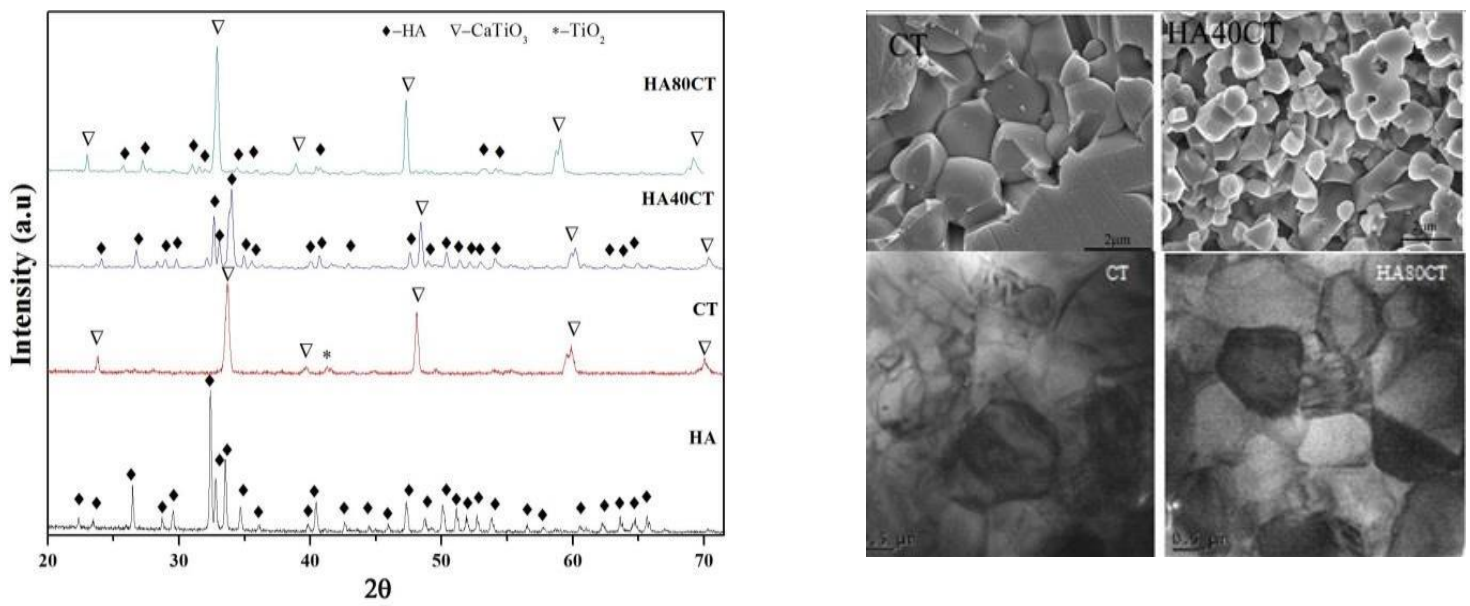

Figure 1(a) and (b): XRD spectra and SEM and TEM microstructure of monolithic HA, CT ceramics and HA-CT composites 

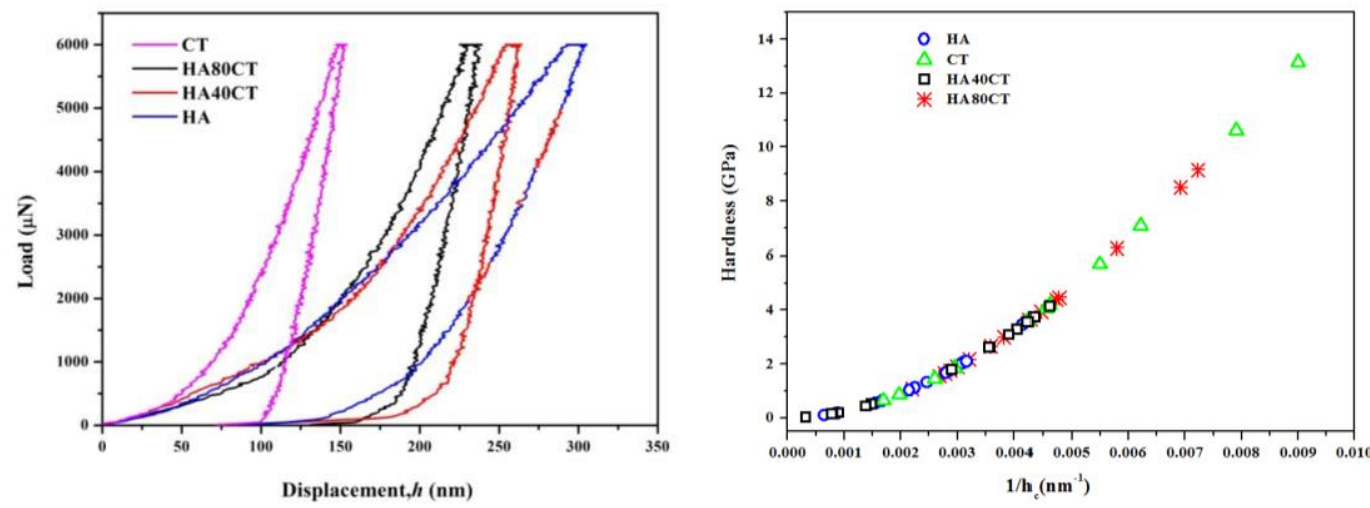

Figure 2 (a) and (b): Typical loading and unloading nanoindentation curves and stiffness of HA, CT, HA40CT and HA80CT composites at peak load of $6 \mu \mathrm{N}$
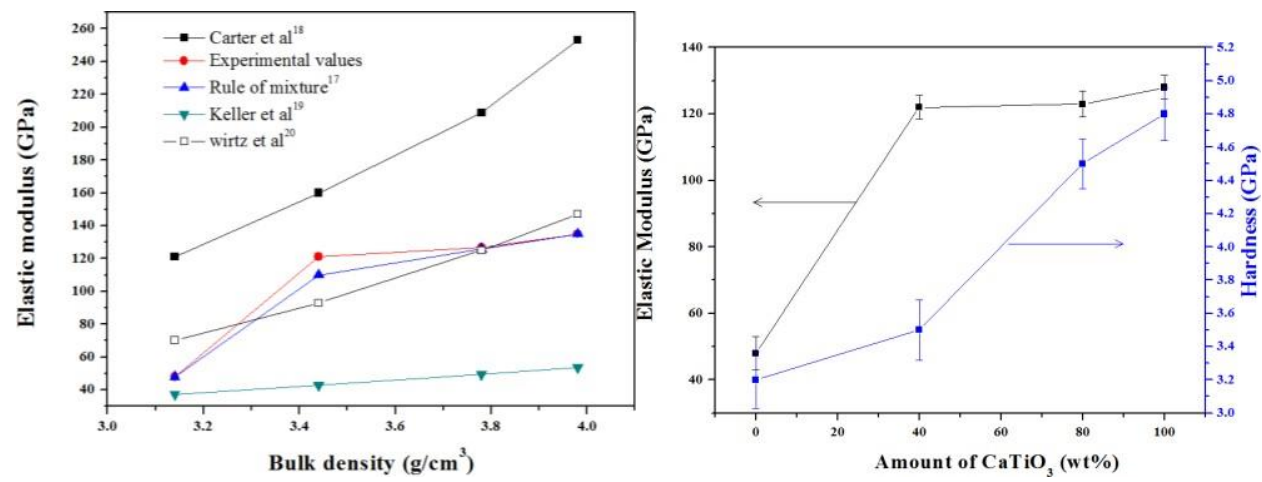

Figure 3 (a): Elastic modulus of HA-CT composites compare with different models as a function of bulk density and (b) Elastic modulus of HA-CT composites compare with hardness as function of wt\% of $\mathrm{CaTiO}_{3}$

\section{References}

1. Hench L.L, Bioceramics, J.Am.Ceram.Soc., 1998, 81(7), 1705-1728

2. Ducheyne P., Qiu, Q. Bioactive ceramics: the effect of surface reactivity on bone formation and bone cell function, Biomaterials, 1999, 20, 2287-2303

3. Suchanek, W., Yoshimura, M., Processing and properties of hydroxyapatite-based biomaterials for use as hard tissue replacement implants. Journal of Materials Research, 1998, 13 (01), 94-117

4. Nath S., Biswas K., Wang K., Bordia R. K., Basu B., Sintering, Phase Stability, and Properties of Calcium Phosphate-Mullite Composites. Journal of the American Ceramic Society, 2010, 93 (6), 1639-1649

5. Ignjatović N., Savić V., Najman S., Plavšić M., Uskoković, D., A study of HAp/PLLA composite as a substitute for bone powder, using FT-IR spectroscopy. Biomaterials, 2001, $22(6), 571-575$

6. Goller G., Demirkıran H., Oktar F. N., Demirkesen E., Processing and characterization of bioglass reinforced hydroxyapatite composites. Ceramics international, 2003, 29 (6), 721-724 
7. Coreno J., Coreno O., Evaluation of calcium titanate as apatite growth promoter, Journal of Biomedical Materials Research Part A, 2005, 75 (2), 478-484

8. Webster T. J., Ergun, C., Doremus R. H., Lanford W. A., Increased osteoblast adhesion on titanium-coated hydroxylapatite that forms $\mathrm{CaTiO}_{3}$, Journal of Biomedical Materials Research Part A,2003, 67 (3), 975- 980

9. Ramírez M. A., Parra R., Reboredo M. M., Varela J. A., Castro M. S., Ramajo L., Elastic modulus and hardness of $\mathrm{CaTiO}_{3}, \mathrm{CaCu}_{3} \mathrm{Ti}_{4} \mathrm{O}_{12}$ and $\mathrm{CaTiO}_{3} / \mathrm{CaCu}_{3} \mathrm{Ti}_{4} \mathrm{O}_{12}$ mixture, Materials Letters 2010, 64 (10), 1226-1228

10. Yang, Z.; Yamada, H.; Miller, G. R., The effects of dopant addition on sintering, electrical conductivity, fracture strength, and corrosion resistance of polycrystalline $\mathrm{CaTiO}_{3}$, Journal of materials science, 1986, 21(2), 405-410

11. Dubey A. K., Tripathi, G., Basu B., Characterization of hydroxyapatite-perovskite ( $\left.\mathrm{CaTiO}_{3}\right)$ composites: Phase evaluation and cellular response, Journal of Biomedical Materials Research Part B: Applied Biomaterials, 2010, 95(2), 320-329

12. Madhav Reddy K., Kumar N., Basu B., Innovative multi-stage spark plasma sintering to obtain strong and tough ultrafine-grained ceramics, Scripta Materialia, 2010, 62(7), 435438

13. Santos M. H., Oliveira M., Souza L. P. F., Mansur H. S., Vasconcelos W. L., Synthesis control and characterization of hydroxyapatite prepared by wet precipitation process, Materials Research, 2004, 7(4), 625-630

14. Vukotić V., Radojević N., Živković L., Vuković Z., Stojanović B., In Mechanically Activated Synthesis of $\mathrm{CaTiO}_{3}$ from Mixture of $\mathrm{CaO}$ and $\mathrm{TiO}_{2}$, Trans Tech Publ, 2005, 393-398

15. Juang H. Y., Hon M. H., Effect of calcination on sintering of hydroxyapatite, Biomaterials, 1996, 17(21), 2059-2064 